\title{
The Routledge Companion to Iberian Studies
}

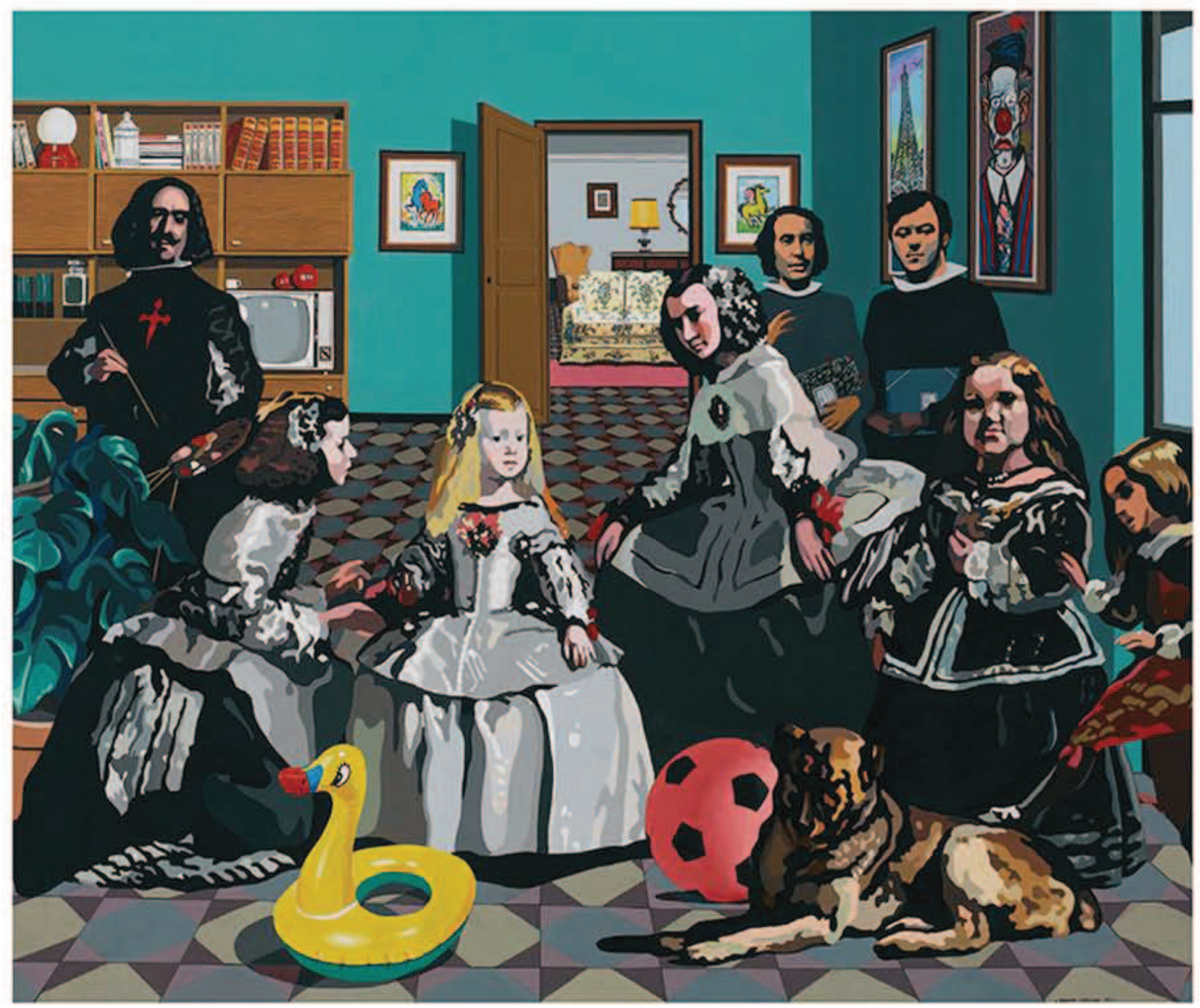

Edited by Javier Muñoz-Basols, Laura Lonsdale and Manuel Delgado 


\section{PRAISE FOR THIS EDITION}

A remarkable collection of in-depth essays on a vast array of topics relating to Iberian cultures across the ages. Rather than focusing on Spain as an isolated unit, this book encourages readers to view Iberia as a whole - a multifaceted, multicultural entity in which diverse languages, traditions, and histories come into play. Interdisciplinary in concept, it includes essays on politics and art, literature and geography, economics and religion, history and visual culture by acclaimed experts from both sides of the Atlantic. The articles on Irish cultural influences in Spanish are particularly refreshing. The articles on women during different periods of Iberian history help to provide a comprehensive view of Iberian society. Also extremely innovative are the sections on twentieth and twenty-first-century Iberia, which offer not only a new look at the rise of fascism and the civil war, but also groundbreaking work on Spanish film, television and popular literature, including comics. This is a book that all Hispanicists will want to have on their bookshelves.

Professor Barbara Mujica, Georgetown University

A timely and engaging exploration of the new mapping of the field. In less than a decade, the debate about the need to shelve monologic and monolithic versions of Hispanism and replace them with a more plural relational approach has taken centre stage. There is growing consensus that the cultural, historical and political complexity of the territory cannot be addressed within traditional disciplinary borders with the old methodological tools. This book is a response to demands to put the reconfiguration of the field into practice. Many of the leading scholars in Iberian Studies have contributed to this monumental collection that demonstrates the justification and rewards of a comparative perspective. It derives some fruitful lessons from the application of the premises of Comparative Literature to the internal differences and tensions in the Peninsula, and to the interaction between forms of cultural production. The most complete picture of the landscape is thus achieved by means of a prismatic composition: the sum of diverse fragments gives us a view of the whole.

Professor Antonio Monegal, Universitat Pompeu Fabra

A superbly rich collection of 50 articles by scholars deploying multiple approaches to the diverse cultures of Iberia, medieval to present day. A few samples: a witty history of the Camino de Santiago; articles on translation, medieval, Franco era and present day; on medieval 
hermeneutics and premodern subjectivity in the Libro de buen amor; on Alvar Núñez and sixteenth-century mapping; on blood (im)purity in Iberia and Iberian colonies; on paintings of the morisco expulsion; rehearsal scenes and the comedia as prompt book for a changing society; on Icarus and Phaethon in Golden Age cultural production; on Enlightenment painting; on women writers - medieval convent voices, Enlightenment Hispano-Irishwomen, Rosalía de Castro, and female detective novels; on the rise and demise of Iberian empires, on civil wars, nation formations, changing political vocabularies, city planning, Basque and Catalán cultures, cinema and graphic novels; and much, much more to savor. In all, an excellent contribution to the several fields of Hispanic studies, and given its interdisciplinary focus, to students and scholars in history, translation studies, art history, theater studies, women's studies, political science and cultural anthropology as well.

Professor Margaret R. Greer, Duke University

This impressive book is an essential tool for research in Iberian Studies. The wide range of topics that are dealt with in this Companion constitutes a highly comprehensive view of Iberian history, politics and culture together with literature and visual arts. With contributions written by most prestigious scholars, the Companion offers a complete exploration of key topics from a systematic and historical perspective, providing a comparative foundation for the understanding of a complex reality. The depth of the articles makes it possible to read each contribution both as a coherent part of a whole and as a single work. The variety of topics guarantees the usefulness of this indispensable volume for all readers and researchers in Iberian culture.

\section{Professor Tomás Albaladejo, Universidad Autónoma de Madrid}

Following Resina's pioneering call for a more transnational understanding of the Iberian condition, these 50 essays, by scholars of different lands and generations, fully succeed at breaking traditional academic barriers and hierarchies: The Companion, organized chronologically from the Middle Ages to the 21st Century, explores, often in comparative fashion, the complex political, cultural - visual/textual - , social and historical tapestry of the Peninsula, unconstrained by language, field, nationality, gender or race. Moreover, the notion of "Iberian Studies," born in the era of globalization, is not here another form of compartmentalization, for it necessarily interacts with other "studies" and their modes of analysis. Media Studies, Afro-Iberian Studies, Visual Studies, and Global studies, among others, become commensurate and indispensable interlocutors. Such equitable dialogue is particularly illuminating when its subjects traverse or confront by definition multiple languages and territories: pilgrimage, nationalism, empire, cartography, emigration/exile and, repeatedly, translation, as much from a "foreign" language as between "national languages." 


\section{THE ROUTLEDGE COMPANION TO IBERIAN STUDIES}

The Routledge Companion to Iberian Studies takes an important place in the scholarly landscape by bringing together a compelling collection of essays that reflect the evolving ways in which researchers think and write about the Iberian Peninsula.

\section{Features include:}

- A comprehensive approach to the different languages and cultural traditions of the Iberian Peninsula;

- Five chronological sections spanning the period from the Middle Ages to the twentyfirst century;

- A state-of-the-art account of the field, reaffirming Iberian Studies as a dynamic and evolving discipline with promising areas for future research;

- An array of topics of an interdisciplinary nature (history and politics, language and literature, cultural studies and visual arts), focusing on the cultural distinctiveness of Iberian traditions;

- New perspectives and avenues of inquiry that aim to promote a comparative mode within Iberian Studies and Hispanism.

The fifty authoritative, original essays provide readers with a diverse cross-section of texts that will enrich their knowledge of Iberian Studies from an international perspective.

Contributors: Samuel Amago, Rachel L. Burk, Rodrigo Cacho Casal, Jordi Canal, Isabel Capeloa Gil, Enric Castelló, Manuel Castiñeiras, Jesús Cruz, Frederick A. de Armas, Antonia L. DelgadoPoust, John Edwards, Brad Epps, George Esenwein, Sebastiaan Faber, Javier Fernández Sebastián, Antonio Feros, Robert Folger, Elizabeth Franklin Lewis, Benjamin Fraser, E. Michael Gerli, Richard Gillespie, George D. Greenia, Michelle M. Hamilton, David K. Herzberger, Jonathan Jarrett, María Liñeira, Laura Lonsdale, José Luis Martí, Elisa Martí-López, Kathryn M. Mayers, Raquel Merino-Álvarez, Javier Muñoz-Basols, Micaela Muñoz-Calvo, Rosa Navarro Durán, Mari Jose Olaziregi, Santiago Pérez Isasi, Alexander Ponsen, Ronald Puppo, Richard Rabone, Pamela Radcliff, Helen Rawlings, Joan Ramon Resina, Filipe Ribeiro de Meneses, Cristián H. Ricci, Alberto Romero Ferrer, Teofilo F. Ruiz, Agustín Sánchez Vidal, Julio-César Santoyo, Andrew Schulz, Jonathan Thacker, Lesley K. Twomey and David A. Wacks.

Javier Muñoz-Basols is Senior Instructor in Spanish and Co-ordinator of the Spanish language programme at the University of Oxford.

Laura Lonsdale is Associate Professor of Spanish at the University of Oxford and Fellow of The Queen's College.

Manuel Delgado is Professor of Spanish at Bucknell University. 
$\because$ Taylor \& Francis

Taylor \& Francis Group

http://taylorandfrancis.com 


\title{
THE ROUTLEDGE COMPANION TO IBERIAN STUDIES
}

\author{
Edited by Javier Muñoz-Basols, \\ Laura Lonsdale and Manuel Delgado
}


First published 2017

by Routledge

2 Park Square, Milton Park, Abingdon, Oxon OX14 4RN

and by Routledge

711 Third Avenue, New York, NY 10017

Routledge is an imprint of the Taylor \& Francis Group, an informa business

(C) 2017 selection and editorial matter, Javier Muñoz-Basols, Laura Lonsdale and Manuel Delgado; individual chapters, the contributors

The right of Javier Muñoz-Basols, Laura Lonsdale and Manuel Delgado to be identified as the authors of the editorial material, and of the authors for their individual chapters, has been asserted in accordance with sections 77 and 78 of the Copyright, Designs and Patents Act 1988.

All rights reserved. No part of this book may be reprinted or reproduced or utilised in any form or by any electronic, mechanical, or other means, now known or hereafter invented, including photocopying and recording, or in any information storage or retrieval system, without permission in writing from the publishers.

Trademark notice: Product or corporate names may be trademarks or registered trademarks, and are used only for identification and explanation without intent to infringe.

British Library Cataloguing-in-Publication Data

A catalogue record for this book is available from the British Library

Library of Congress Cataloging-in-Publication Data

Names: Muñoz-Basols, Javier editor. | Lonsdale, Laura, editor. Delgado, Manuel, 1944- editor.

Title: The Routledge companion to Iberian studies / edited by Javier Muñoz-Basols, Laura Lonsdale and Manuel Delgado.

Description: London; New York : Routledge, 2017. | Includes bibliographical references and index.

Identifiers: LCCN 2016039697 | ISBN 9780415722834 (hardback : alk. paper) | ISBN 9781315709895 (ebook)

Subjects: LCSH: Iberian Peninsula - Civilization. | Iberian PeninsulaIntellectual life. | Spain - Civilization. | Spain-Intellectual life.

Portugal-Civilization. | Portugal-Intellectual life. | Iberians.

Classification: LCC DP48 .R68 2017 | DDC 946.00072-dc23

LC record available at https://lccn.loc.gov/2016039697

ISBN: 978-0-415-72283-4 (hbk)

ISBN: 978-1-315-70989-5 (ebk)

Typeset in Times New Roman

by Apex CoVantage, LLC 


\section{CONTENTS}

List of figures

xiii

Notes on contributors $x v$

Preface xxii

Acknowledgements xxv

PART I

Medieval Iberia (eighth-fifteenth centuries) 1

History, politics and cultural studies 3

1 Festive traditions in Castile and Aragon in the late Middle Ages:

ceremonies and symbols of power 5

Teofilo F. Ruiz

2 Faith and footpaths: pilgrimage in medieval Iberia 16

George D. Greenia

3 Before the Reconquista: frontier relations in medieval Iberia, 718 to $1031 \quad 27$ Jonathan Jarrett

4 The faiths of Abraham in medieval Iberia

John Edwards

5 Medieval Iberian cultures in contact: Iberian cultural production as translation and adaptation

Michelle M. Hamilton 
Literature and visual culture

6 Court and convent: senses and spirituality in Hispanic medieval women's writing

Lesley K. Twomey

7 An interstitial history of medieval Iberian poetry

David A. Wacks

8 Revisiting the history of medieval translation in the Iberian Peninsula Julio-César Santoyo

9 Subjectivity and hermeneutics in medieval Iberia: the example of the Libro de buen amor

Robert Folger

10 Patrons, artists and audiences in the making of visual culture in medieval Iberia (eleventh-thirteenth centuries)

Manuel Castiñeiras

\section{PART II}

The Iberian Peninsula in the Golden Age (sixteenth-seventeenth centuries)

History, politics and cultural studies

11 The early modern Iberian empires: emulation, alliance, competition Alexander Ponsen and Antonio Feros

12 The Iberian Inquisitions in the sixteenth and seventeenth centuries: between coercion and accommodation

Helen Rawlings

13 The way behind and the way ahead: cartography and the state of Spain in Cabeza De Vaca's Relación

Kathryn M. Mayers

14 Purity and impurity of blood in early modern Iberia Rachel L. Burk

15 The expulsion of the Moriscos: seven monumental paintings from the kingdom of Valencia

E. Michael Gerli 
Literature and visual culture

16 The influence of Tirant lo Blanch on Golden Age Iberian authors Rosa Navarro Durán

17 Women from the periphery in Don Quixote: ekphrasis versus counter-narrative

Frederick A. de Armas

18 "Para tiempos de veras / se ejercitan en las burlas:" some uses of rehearsal on the Golden Age stage

Jonathan Thacker

19 Iberian myths and American history in Balbuena's El Bernardo Rodrigo Cacho Casal

20 Fallen idols? Vice and virtue in the iconography of Icarus and Phaethon

Richard Rabone

\section{PART III}

The Iberian Peninsula in the eighteenth and nineteenth centuries

21 Hispano-Irish women writers of Spain's late Enlightenment period Elizabeth Franklin Lewis

22 The end of empire and the birth of the modern nation, 1808 to 1868

Jesús Cruz

23 Carlists against liberalism: counter-revolution in the Iberian Peninsula during the nineteenth century Jordi Canal

24 From patriotism to liberalism: political concepts in revolution Javier Fernández Sebastián

25 The modern city, 1850 to 1900: urban planning and culture in Barcelona, Madrid and Bilbao Benjamin Fraser 
Literature and visual culture

26 Building nations through words: Iberian identities in nineteenthcentury literary historiography

Santiago Pérez Isasi

27 The poetized peopling of nineteenth-century Spain/s

Ronald Puppo

28 Death and the crisis of representation in Narcís Oller's La febre d'or and Pérez Galdós's La de Bringas

Elisa Martí-López

29 Performing the Peninsula: costumbrismo and the theatre of the eighteenth and nineteenth centuries

Alberto Romero Ferrer

30 Painting in the Spanish Enlightenment: artists at court and in the academy

Andrew Schulz

PART IV

The Iberian Peninsula during the twentieth century

History, politics and cultural studies

31 The idea of empire in Portuguese and Spanish life, 1890 to 1975

401

Filipe Ribeiro de Meneses

32 The fate of Spain's "nationalisms" during the Spanish Civil War, 1936 to 1939

George Esenwein

33 Beyond the nation: Spanish Civil War exile and the problem of Iberian cultural history

Sebastiaan Faber

34 Translation and censorship under Franco and Salazar: Irish theatre on Iberian stages

Raquel Merino-Álvarez

35 Unsettling the Iberian transitions to democracy of the 1970s

Pamela Radcliff 
Literature and visual culture

36 Buñuel, Lorca, and Dalí: a new tradition

Agustín Sánchez Vidal

37 Reclaiming the goods: rendering Spanish-language writing in

Catalan and Galician

María Liñeira

38 Postwar Spanish fiction and the pursuit of Spanish reality

David K. Herzberger

39 Celluloid consensus: a comparative approach to film in Portugal during World War II Isabel Capeloa Gil

40 (Inter)national spectres: cinema in mid-twentieth-century Iberia Brad Epps

\section{PART V}

Iberian studies in the twenty-first century

History, politics and cultural studies

41 Pro-sovereignty politics in Catalonia and the Basque Country: are the two cases comparable?

Richard Gillespie

42 Going global: the international journey of Basque culture and literature

Mari Jose Olaziregi

43 Democracy, indignados, and the republican tradition in Spain

José Luis Martí

44 Mediatizing a past of conflict: the Spanish Civil War through TV documentaries in the twenty-first century Enric Castelló

45 A transmodern approach to Afro-Iberian literature Cristián H. Ricci 
Literature and visual culture

46 Fermented memory: the intemperance of history in the narrative of Ramón Saizarbitoria Joan Ramon Resina

47 Of treasure maps and dictionaries: searching for home in Carlota Fainberg, Bilbao-New York-Bilbao and L'últim patriarca Laura Lonsdale

48 Rewriting the Iberian female detective: deciphering truth, memory, and identity in the twenty-first-century novel Antonia L. Delgado-Poust

49 Reflexivity in Iberian documentary film Samuel Amago

50 Human memory and the act of remembering in contemporary Iberian graphic novels Javier Muñoz-Basols and Micaela Muñoz-Calvo 


\title{
34
}

\section{TRANSLATION AND CENSORSHIP UNDER FRANCO AND SALAZAR}

\section{Irish theatre on Iberian stages ${ }^{1}$}

\author{
Raquel Merino-Álvarez
}

For most of the twentieth century the totalitarian regimes of Franco in Spain (1939-1975) and Salazar in Portugal (1933-1974) influenced Spanish and Portuguese cultural production, and theatre life in particular. Both dictatorships are the backdrop against which the study of theatrical culture on Iberian stages are tackled in this contribution by gauging the role of censorship in favouring or opposing the importation of foreign (Irish) drama.

Apart from the obvious chronological parallelism - Salazar's Estado Novo was founded three years before the beginning of the Spanish Civil War and came to an end barely a year before the demise of Francoism - the two Iberian dictatorships share obvious traits, but at the same time differ visibly when subjected to scrutiny. The foremost difference can be found in the way both regimes were born: the Portuguese out of a referendum and a "political" Constitution (Pena 2013), the Spanish counterpart as a result of a cruel civil war in which foreign forces took active part.

When comparing "two mutually inimical authoritarian regimes," the Portuguese and the Czechoslovak, Spirk affirms that they "actually had more in common than meets the eye" $(2014,23)$. The reverse may be said of the two seemingly friendly Iberian regimes. From the outset the political and economic circumstances in both countries were radically different. Spain, devastated after the Civil War, was perceived as a crucial front and a silent battleground where Axis forces fought to gain influence and challenge the position of the Allies, whereas neutral Portugal profited from trade with both Germany and Britain, and its territory was not considered crucial for the unfolding of WWII.

The effects of censorship under Salazar in relation to translation have been at the centre of recent research projects (Seruya 2009) focused mainly on printed literature. In Spain, under the auspices of the TRACE project, the history of translated literature, theatre and cinema in the Franco era has been mapped out. However, very little comparative research of the two Iberian contexts has been published to date: Fiuza's (2009) study of censored popular music being an exception.

\section{Foreign ("English") theatre on Iberian stages}

Published histories of (Spanish) theatre have traditionally overlooked the role played by translations, placing their focus on the "national" rather than the "foreign." The sporadic references found in such histories do not usually serve as a starting point to reconstruct the history 
of theatre in (Spanish) translation (Delgado and Gies 2012; Huerta 2003). ${ }^{2}$ Research based on references in the daily press (Mahanta 1994) or compilations of publications linked to stage productions (Puebla 2012) usually adopt a more inclusive view, not excluding translated drama. In this respect, the Spanish censorship archives (AGA) have been paramount in attempting to reconstruct the history of translated theatre on Spanish stages. Translations of foreign theatre played a central role in the very existence of Spanish theatrical life; they helped renew topics and contributed both quantitatively and qualitatively to the development of stage productions; hence the need for an account of the plays, authors and topics that found their way onto Spanish stages via translation. The compilation of catalogues of translations and the study of textual corpora has been at the centre of TRACE (Spanish censorship) studies (Merino 2009, 2012). Since all productions had to seek official permission from the Francoist bureaucratic censorship offices, the traces left in the form of millions of documents are an exceptional documentary resource to mine. The Portuguese archives at the Torre do Tombo have also been instrumental in compiling databases of theatre translations (TETRA) or bibliographies of printed translations (Seruya 2009).

We have consulted TETRA and CETbase for information on theatre productions in Portu$\mathrm{gal}$, and the AGA (Spanish censorship archives, theatre section) and TRACE-theatre databases for the Spanish situation. A comparative overview of these sources shows that Anglophone cultures (British and US) seem to have prevailed in both Iberian contexts. In Portugal, plays originally written in English were often imported through the more influential French language and culture (Seruya 2009, 82). The events leading up to WWII made the leanings of Portugal and Spain gravitate from pro-German to Anglophile positions, with the pro-English stance remaining established from the mid 1940s onwards.

So far the TRACE (Translation and Censorship) project has identified a substantial corpus of translated drama texts and provided a comprehensive catalogue of productions of foreign theatre in Spain. These catalogues show the pre-eminence of Anglophone (British) drama since the 1940s and the quantitative and qualitative presence of plays by US authors since the 1950 s, with plays by Irish authors to be found across the twentieth century in Spanish productions. In terms of numbers, the situation of Anglophone Irish theatre may be compared with that found in Portugal (Carvalho 2009a) or even in a non-totalitarian European country such as Finland (Aaltonen 1996).

The CETbase, established in 1992 by the Centro do Estudos de Teatro, is a general database of stage productions in Portugal, whereas the TETRA (Theatre Translation) project database has specifically addressed the issue of censorship. Carvalho has dealt with translations of Irish theatre in Portugal, drawing data from CETbase (2009a, 599). The data available for Portugal has been contrasted with the information compiled for a specific catalogue of translations (productions) of plays by Irish authors and drawn from AGA-censorship archives (TRACEtirl, www.ehu.es/trace). These sources, when compared, allow us to establish similarities and differences between the Portuguese and Spanish theatrical systems, in relation to the importation of plays originally written in English by Irish authors, under similar censorship restrictions (see Appendix).

Carvalho $(2009 \mathrm{a}, 85)$ cites a compilation by theatre historian Jose Luiz Rebello of foreign theatre plays staged in Portugal between January 1940 and December 1949 which shows that Spain and France ( 48 and 46 entries, respectively) were the main sources of foreign imports, followed by Britain (17), Hungary (11) and the US (8). Carvalho's corpus, for the period 1956-2005, includes a total of 40 productions of Irish playtexts (2009a, 22).

In the case of Spain, (British and Irish) English playtexts were imported via translation right after the Civil War, with American melodrama of the pre-war period still present on 
Spanish stages (Pérez 2005). In 1942, a pioneering production of Priestley's Time and the Conways, in the María Guerrero Theatre, directed by Luis Escobar-Kirpatrick, and possibly instigated by the director and founder of the British Institute in Madrid, the Irishman Walter Starkie (London 1997, 64), is reviewed and praised in the press alongside a film directed by Kimmich (Goebbels's brother-in-law) and the military fund-raising show of the Italian Fascio ( $A B C$, November 18, 1942, 12).

Although Escobar sided ideologically with the Franco government after the war, and was even deemed pro-German (Quirós 2010), as head of the María Guerrero Theatre he tried to continue the theatrical tradition first established by La Barraca group with whom he had cooperated, albeit without the group's ideological agenda. Escobar's Anglo-Spanish origin favoured his role as influential mediator and successful translator. As director of one of the national theatres, he was persuaded to import most British plays from London's West End, as a means to counteract German influence on Madrid's stages at critical moments for the allies in WWII (García 2007, 96; London 1997, 41), and he also spent some time in London with funding from the British Council in the mid 1940s.

\section{Irish theatre on Iberian stages: Shaw, Wilde, Beckett}

The Spanish AGA censorship archives database for theatre performances record slightly more than 100 entries of plays by Irish authors. A direct search in the AGA files has led to a compilation of a larger catalogue of 200 translations of plays by Irish authors. From a quantitative point of view, entries for productions of Beckett's plays, along with those by Wilde and Shaw, make up two thirds of the total, while translations of plays by O'Casey and Synge represent barely $15 \%$ of the catalogue. Lastly, entries for Behan, Joyce or Yeats are restricted to sporadic productions.

In Portugal Irish authors were staged from the mid 1950s onwards (Carvalho 2009a, 599-607), starting with the 1956 premiere of Synge's Riders to the Sea or the 1959 production of Beckett's Waiting for Godot, establishing a trend in favour of Irish theatre as vehicle for the renovation of Portuguese theatrical repertoires (Carvalho 2005).

Among the first theatre productions to be staged after the Spanish Civil War are Oscar Wilde's Lady Windermere's Fan (1940), A Woman of no Importance and Salomé (1941). Wilde's plays were staged at a rate of about one per year in the 1940s, a tendency that slowed down in the 1950s and 1960s, only to return in the 1970s (Constán 2009) and continue well into the twenty-first century (Mateo 2010).

Spanish productions of Shaw's plays began with Candida (1941) and Pygmalion (1942) and continued at a steady pace through to the end of the 1970s (Isabel-Estrada 2001). Most of the translations of Wilde and Shaw produced in the period had been published before the Civil War, and new productions as well as translations of the more popular plays were put on stage. Both authors were considered (and labelled) "English" rather than "Irish," and given their well-established status in Europe, they were not deemed dangerous by censors on the whole. Wilde's Salomé was staged eight times during the Franco years, but was also the most polemical and so was occasionally banned or given the same restrictive classifications applied in the US (Sova 2004, 238). Wilde's The Importance of Being Earnest was staged six times, as was Shaw's Pygmalion, without much resistance from the censorship offices. Major Barbara and Mrs. Warren's Profession found more opposition and were banned in the first instance (Isabel-Estrada 2001).

In Portugal, Wilde and Shaw seem to have been perceived as established "English" classics (Marques dos Santos 2012; Ramos 2010, 2012), and are thus not included in studies on 
the reception of Irish theatre in Portugal, their plays not dealing with themes "specifically Irish or representing Ireland" (Carvalho 2009a, 16). ${ }^{3}$ An exception is made for Beckett in Carvalho's study in considering him an extra-territorial author (Carvalho 2009a, 263-310). Beckett's plays were frequently staged in Portugal from 1959 onwards: all of his plays have been translated into Portuguese (Fernández 2009), and most have been produced by experimental groups.

Samuel Beckett is not specifically identified as Irish in Spain either. The premiere of Waiting for Godot in 1955 marked the beginning of a constant presence of his plays in productions for club sessions by independent groups. Beckett is labelled "English," "French" or "Irish" in the censorship records consulted, and it is not unusual to find references to the Paris or London productions of his plays in the reports by censors or in documentation submitted by the theatre groups. Martínez-Trives, translator and champion of Beckett's plays in Spain, impressed by the 1953 production of Waiting for Godot in Paris, decided to have it staged in Spanish (Fernández 2009). In the AGA censorship records consulted, Beckett seems to be perceived as an experimental playwright, whose plays are quite incomprehensible for the common censor, and therefore not considered especially dangerous.

\section{Irish theatre on Iberian stages: O'Casey, Synge, Yeats}

If some authors such as Shaw and Wilde are not specifically perceived as "Irish," but rather as "English" classics, or culturally hybrid (Beckett), then John Millington Synge and Sean O'Casey, along with W. B. Yeats, are playwrights committed to an Irish identity that has been highlighted in both Iberian contexts.

Reconstructing the introduction and development of Spanish productions of O'Casey's plays is an interesting exercise that provides an overview of the evolution of Spanish theatre under Franco's dictatorship. The first play to be granted permission for the stage is Juno and the Paycock in 1955, first staged in Finnish in 1952 (Aaltonen 1996, 221) and in French in 1953. The application was submitted to the censor by Enrique Llovet, at the time Spanish consul in Paris, and filed under Llovet's name as translator and Walter Starkie's as O'Casey's representante in Spain (AGA record no. 109/55). Starkie had been director of the British Institute in Madrid (1940-1954) but before that he occupied the chair of Spanish at Trinity College Dublin, where Llovet had been a student. Starkie favoured the presence of authors from the British Isles on Spanish stages, and his influence in theatre circles is made clear by this early successful introduction of O'Casey to Spanish audiences.

In 1955, the official register for Teatros de Cámara (experimental studio, theatres) was established, which allowed small theatre groups to present avant-garde productions imported from Paris, London or New York, while permitting Spanish authorities to demonstrate abroad that Spain was already in tune with Europe and willing to be included in international affairs.

The 1964 approval for a production of End of the beginning / Pin y pon hacen sus labores (AGA record no. 217/64), followed by Bedtime Story / Cuento para la hora de acostarse in 1966 (AGA record no. 274/66) directed by Enzo Casali, and Red Roses for Me / Rosas rojas para mí directed by José María Morera in 1967 (AGA record no. 226/67) consolidated O'Casey in Spain, coinciding with the short period of "apertura," or opening up, from within the Ministry for Information and Tourism (Theatre and Cinema Division) under Manuel Fraga (Muñoz-Cáliz 2006). The 1969 translation by Spanish playwright Alfonso Sastre of Red Roses for Me (AGA record no. 258/69) proved more polemical, as did Cock-a-Doodle Dandy/Canta gallo perseguido (AGA record no. 446/73) in 1973. With a change of ministerial team in 1969 , a harsher censorship policy was applied: many applications were delayed or rejected. The 
clash between a modern progressive society and a regressive government resulted in a theatrical upheaval by 1975. Just before the death of Franco (1975), productions of controversial plays were not only granted permission for commercial productions but also became hugely successful: Peter Shaffer's Equus (with male and female nudity on stage), the musical Jesus Christ Superstar (with its irreverent perspective of the Christian religion) or Crowley's depiction of a party of homosexuals in The Boys in the Band (Merino 2007, 243-286).

Opposition and resistance from within the censorship offices were counteracted by applications for plays by foreign authors, usually manipulated to fit specific political agendas. In this context, the socialist O'Casey, whose plays circulated in East Germany and the Soviet Union, but also in the network of French state-subsidized theatres (Moran 2013, 157), was chosen by playwright Alfonso Sastre, a member of the Communist Party, to help boost the presence of socialist ideas on Spanish stages.

The censorship process leading up to the 1973 production of Cock-a-Doodle-Dandy was fraught with interventions from all possible fronts. The first application, submitted by director Adolfo Marsillach, was presented with the translation by Ana Antón Pacheco, published (along with Oak Leaves and Lavender) by Cuadernos para el Diálogo in 1972. The text, a copy of the published book, was accompanied by a note from the director stating that the "harsh" language of the Spanish translation "needs to be softened," and one of the censors (Zubiaurre) affirmed in his report that the play "has been feebly translated." Problematical sections were discussed by censors and negotiated with the director, specifically those felt to be attacks on Catholics and Catholicism. The successive versions of the Spanish text submitted to the censor are signed by the Spanish playwright Antonio Gala. Additional documentation in the record shows that the original translator (Ana Antón-Pacheco) filed a complaint and a request to have the censorship office check whether the so-called version by Gala was in fact her own translation slightly modified. Upon consultation with the legal department, a letter is sent to the translator stating that the censorship offices were not in charge of copyright matters. In a newspaper interview on the occasion of the premiere, Gala explains how he had been asked to write a version of Cock-a-Doodle-Dandy and explains that, as author of the version, he had "re-created" O'Casey's text, that "the essence" of the original text had not been modified but made more "perceptible" and "acceptable" to Spanish ears by making lines "lighter and faster." Gala remarks that by being "unfaithful" to O'Casey, by modifying and substituting the author's expressions, he managed to better serve O'Casey $(A B C$, November 30, 1973, 89).

O'Casey was often staged in Spain in the 1960s, a time of apertura from within the regime, and his plays seemed to be well-established in Spanish theatre, but in the troubled early 1970s the Esperpento theatre group's production of A Bedtime Story, after a successful tour in Europe and around Spain $(A B C$, May 10, 1973, 46), ended with an abrupt cancellation by the military authorities for alleged insults against the army, and the five members of Esperpento were nearly taken before a military tribunal (AGA record no. 274/66; El Faro de Vigo, June 1, 1973). The same year, 1973, Alfonso Sastre published his Spanish version of Shadow of a Gunman / Irlanda, Irlanda with an introduction on the struggle of the Irish to gain independence. In an interview (http://www.jornada.unam.mx/2005/01/02/102e1cul.php) he confirmed that he wanted to prompt the setting up of a Basque independent theatre following the Irish example.

Sean O'Casey's works were translated and published in Portugal from the 1960s (Carvalho 2009b), but while Portuguese editions were readily available, productions of his plays were performed only after Salazar's regime was over. The premiere of Hall of Healing by a professional group took place in 1976. But the first application to stage the play, filed in the early 1960s, resulted in a ban and the ensuing "non-production." Follow-up of the Portuguese 
censorship records for O'Casey's Hall of Healing (Fundo de Teatro, 11A-7763 6395 and 7763) (Carvalho 2009a, 233) could be an excellent starting point for further research, very much in line with the study of non-translation of Czech literature under Salazar (Spirk 2014).

A global appraisal of the position of O'Casey's plays on Portuguese stages may be that of a vacuum but the simple statement that $\mathrm{O}^{\prime} \mathrm{C}$ asey was not staged in Portugal until the advent of democracy begs for further research: How many times were his plays submitted to the censor in the 1960s, what reasons were adduced for banning them and who were the various agents involved in the process that resulted in the lack of productions? It is telling that the translation of Hall of Healing, which marks the debut of O'Casey among Portuguese readers back in 1957 and of his belated stage debut (in 1971 by an amateur group and in 1982 by a professional company), corresponds to a play widely popular in Eastern Germany and the Soviet Union (Moran 2013, 157).

While O'Casey's presence in Iberian theatre after 1955 (the year Portugal and Spain became members of the United Nations) is fairly clear, the reception of Synge and Yeats is to be traced in two distinct periods: a few translations of both playwrights appeared before the Civil War, but it was not until the late 1950s onwards that they started to form part of the Spanish and Portuguese repertoires. In Spain there are references to a translation of Synge's Riders to the Sea / Jinetes hacia el mar by Spanish writer Juan Ramón Jiménez and his wife, Zenobia Camprubí, published in 1920 and staged at Madrid's Ateneo in 1921 in a production attended by Spanish dramatist Lorca (Alonso 2009; Andrews 1991, 70; de Toro 2007; London 1997, 233, 127). Also in the 1920s, a Portuguese literary figure, Fernando Pessoa, had plans for a translation of Riders to the Sea (Carvalho 2009a, 167). The Spanish production of Riders to the Sea supposedly influenced the writing of Lorca's Blood Wedding and even inspired him to put on a Spanish production of Playboy of the Western World with the La Barraca theatre group (de Toro 2007, 10).

There were translations of Yeats' works published from 1918 in Spanish, Catalan, Galician and Basque until just before the Spanish Civil War (Hurtley 2006). A symbol of the Irish Literary Revival, Yeats was an inspiration for the Galician Rexurdimento (1920-1936) and was often quoted along with Synge as a successful example of the "Celtic race" (de Toro 2007).

None of the Celtic nationalist connotations found in relation to Yeats and Synge in Galicia seem to have a parallel in Portugal. As Carvalho (2009a, 232) aptly points out, it is the writings of actor-critic Mário Vilaça in the journal Vértice and Luiz Francisco Rebello's 1957/1965 volume Teatro Moderno: Caminhos e Figuras that effectively introduced Irish plays through translation to readers and theatregoers.

Synge arrived on Portuguese stages with a half-century delay (Carvalho 2009a, 159-231). In 1956 the TUP (Porto University Theatre) presented Riders to the Sea, and a year later RTP (Portuguese public television) broadcast the play and Playboy of the Western World was first produced by the TEP (Teatro Estudio Porto). In 1959 Yeat's Cathleen ní Houlihan was staged and Synge's The Tinker's Wedding was refused permission for performance on account of its "bad quality" and "ill-treatment" of the characters of the priest and the father (censorship record 5812 [Carvalho 2009a, 164]).

In the case of Spain, six plays by Synge were staged between 1956, when the National Chamber Theatre (Teatro Nacional de Cámara y Ensayo), under the direction of Modesto Higueras, presented Playboy of the Western World; and 1978, when two so-called ordenación (regulatory) records authorised productions of Playboy of the Western World in Catalan and Well of the Saints in Galician. This was, of course, the year that new freedoms were granted to theatres and the Spanish Constitution was passed in Spain.

Two distinct productions of Playboy of the Western World were authorised in 1961 ( $E l$ farsante más grande del mundo, AGA record no. 147-61) and 1971 (El botarate del mundo 
ocidental, AGA record no. 345-71), respectively. The play was also broadcast by TVE (Spanish public television) in $1969 .{ }^{4}$ Deirdre of the Sorrows, translated into Spanish by theatre critic Alfredo Marqueríe for the Malaga-based group ARA, was granted an extremely lenient approval in 1964 that included a rare permission for radio broadcast (AGA record no. 125-64). Spanish versions of The Tinker's Wedding and Shadow of the Glen were approved in 1969 (AGA records no. 363-69 and 463-69). In 1972, permission was granted for the Galician stage version of Riders to the Sea/Cabalgada cara ó mar by DITEA. DITEA theatre group, under Agustín Magán's direction, staged plays by Osborne, O'Neill and Albee in the 1960s, and produced Synge, O'Casey and Yeats in the 1970s (Rodríguez-Villar 2005). This is the first and only production of the play recorded in the AGA censorship database; the last record for Synge was in 1975 for Well of the Saints (AGA records no. 161-72 and 184-75). One year after the death of Franco, in 1976, DITEA was given permission to stage O'Casey's Red Roses for Me in Galician, coinciding with the Catalan production of the play. ${ }^{5}$

\section{Translation as transculturation and resistance}

In attempting to give an account of Irish theatre productions in Spain and Portugal under totalitarian regimes, we have tried to find similarities and establish parallelisms. It seems apt to affirm that both Iberian regimes share a historical period and a geographical space in the (southern) periphery of Europe. Although Salazar made use of Portuguese propaganda in favour of Franco, he did so more to reaffirm his own position than that of his neighbour. There is little doubt that the Portuguese press controlled by Salazar made sure that Franco was portrayed as a victorious hero in the battle against communism in the Iberian Peninsula, while presenting the Estado Novo as a model to follow in post-war Spain (Pena 2013, 2014). Luso-Spanish relations were not as close as might be expected; in fact, there was a much closer affinity between Portugal and Ireland, at least in the 1940s in relation to the defence of Catholicism and the need to maintain order and traditional values (Szmigiero 2006). Even the form and structure adopted by the censorship apparatus in both Iberian countries was, at best, dissimilar (Merino 2007; Seruya 2009).

The influence of foreign theatre on both theatrical cultures shows a pre-eminence of English as a source language, and Britain (and, with the victory of the Allies in WWII, the US) as source countries. In the case of Spain, the deliberate introduction of British plays served, through the intervention of the British Council, to counteract the influence of German trends (Corse 2013). However, it remains to be established whether a parallel situation occurred in Portugal.

The 1920 translation into Spanish of Synge's Riders to the Sea remains a rare reference, ingrained in a pre-Civil War literary tradition, related to the generations of writers of the period. So are the translations into Spanish, Galician and Catalan of Yeats' works (Hurtley 2006), texts anchored in the pre-war period, often used as examples of the influence of the Irish literary revival authors on their Spanish counterparts. The 1933 translation into Galician of Yeats' Land of Heart's Desire, by the Villar Ponte brothers, first published in the Galician Literary Revival Journal Nos, was used to mark the Day of Galician Literature in 1977. Yeats' text was thus implanted on a Spanish (Galician) stage in an attempt to make Galician nationalism rise from the ashes of the Rexurdimento.

Although Anglophone-Irish theatre was imported into both Spain and Portugal from the 1950 s, the process in each setting was slightly different. In Spain, Irish authors were chosen for reasons of both ideology (O'Casey) and identity (Synge, Yeats), and were instrumental in establishing a struggle in favour of nationalism (and political change) in Galicia, Catalonia and 
the Basque Country. Ireland's political independence from Britain and Irish linguistic identity were taken as models from the periphery of Europe in the periphery of Spain, so that translation was a fundamental part of a transculturation process (de Toro 2007, 54) that led to the assimilation of Irish drama in Spain. In Portugal the wish to accommodate to European stage trends seems to have formed part of a process of renewal of Portuguese repertoires that was intended to counteract the official ideology, but it had no connotations of nationalist identity. In this case, the use of translation to introduce new "foreign" ideas and aesthetics was a form of resistance against the status quo.

Unlike "English" Shaw and Wilde (Coletes 1985; Constán 2009), whose plays had been translated and staged before Franco and Salazar's times, and continued to be staged and published throughout the twentieth century, other "Irish" playwrights, such as O'Casey or Synge, were introduced as belated novelties in both Iberian contexts. In the late 1960s and 1970s, productions in Galician and Catalan were staged because of their inherent "Irishness" or the accompanying political connotations. Productions of plays by Behan in the 1960s, or by Joyce (Uribe-Echevarría and Merino 1994; Merino and Uribe-Echevarría 1996) and Yeats in the 1970s (Alonso 2009; Andrews 1991; de Toro 2007), complete a global perception of Irish theatre produced in Spain. In Portugal, Synge's position on the stage was reinforced with O'Casey's influence in published form.

Beckett was staged in Spain and Portugal without much delay in relation to the ParisLondon premieres, and was soon integrated into the repertoire of experimental companies following European avant-garde trends. Audience protests at the Paris premiere of Waiting for Godot "turned an exclusively Parisian phenomenon into an event reported worldwide" and Beckett "had acquired one of the ingredients of commercial success: the patina of fame" (Morash 2004, 200), making him one of the most popular playwrights to date (Rodríguez Gago 2006).

The study of Irish theatre on Iberian stages has naturally led us to European and international links both for the 1940s and the second half of the twentieth century. The fact that Irish authors were imported for a non-totalitarian context in the (northern) periphery of Europe (Aaltonen 1996), staged in the British Isles and the cultural centres of the European continent (both east and west), confirms Morash's claim that "as much as Irish theatre imagined itself as national, it has always been at its most vibrant when it has been most international" $(2004,275)$.

\section{Notes}

1 University of the Basque Country, UPV/EHU. Consolidated Research Group GIC12/197, Basque Government IT728/13. Project FFI2012-39012-C04-01T and G15/75, MINECO, Spanish Ministry of Economy, Industry and Competitiveness.

2 In the volume edited by Huerta (2003) a short section is devoted to "Foreign Theatre in Spain" between 1900 and 1939 (2575-2600), with just three pages on "English" theatre (2595-2597). The chapter on German theatre does mention the reception and influence of Brecht in Spanish dramatists Buero and Sastre (Huerta 2003, 2997-3019), but there is no mention of the influence of North American drama. The chronological tables (3012-3051) list titles for "Spanish" and "International" theatre without any reference to translations of foreign theatre in Spain. In Delgado and Gies (2012) a few references to translations are found in Chapter 17 ("Theatre under Franco," 341-370).

3 Aaltonen $(1996,221-223)$ includes both authors in her study of Irish drama in Finland.

4 Along with Synge's Playboy of the Western World, O'Casey's Juno and the Paycock (1964), Beckett's Waiting for Godot (1978) and Joyce's Exiles (1979), various pieces by Shaw and Wilde were broadcast on Spanish television in the 1960s and 1970s (http://www.imdb.com).

5 The AGA database records 428 entries for theatre manuscripts submitted in Catalan, 48 in Galician and 35 in Basque. 


\section{Works cited}

Aaltonen, Sirkku. 1996. Acculturation of the Other: Irish Milieux in Finnish Drama Translation. Joensuu: Joensuu University Press.

AGA. "Archivo General de la Administración." Accessed April 30, 2014. http://www.mecd.gob.es/ cultura-mecd/areas-cultura/archivos/mc/aga/fondos-documentales.html.

Alonso Giráldez, José Miguel. 2009. "Jinetes hacia el mar, una traducción afortunada: sobre la recepción en España de John Millington Synge." AEDEAN Nexus. Accessed April 30, 2014. http://aedean. org/?page id $=309$.

Andrews, Jean. 1991. Spanish Reactions to the Anglo-Irish Literary Revival in the Early TwentiethCentury: The Stone by the Elixir. Lewiston, NY: The Edwin Mellen Press.

Carvalho, Paulo Eduardo. 2005. "Dramaturgia irlandesa e teatro português: Alguns elementos para uma cartografia de representações." Cadernos de Literatura Comparada. (Teatro em Tradução) 12-13: $163-176$.

-2009a. Identidades reescritas: figurações da Irlanda no teatro portugués. Porto: Afrontamento. - 2009b. "Um encontro adiado: Sean O'Casey no Portugal do Estado Novo." In Traduzir em Portugal durante o Estado Novo, edited by Teresa Seruya, Maria Lin Moniz, and Alexandra Assis Roca, 229-249. Lisboa: Universidade Católica Editora.

CETbase Database. "Teatro em Portugal." Accessed April 30, 2014. http://ww3.fl.ul.pt/CETbase/.

Coletes, Agustín. 1985. "Oscar Wilde en España, 1902-1928." Cuadernos de Filología Inglesa 1: 17-32.

Constán, Sergio. 2009. Wilde en España. La presencia de Óscar Wilde en la literatura española (1882-1936). León: Akrón.

Corse, Edward. 2013. A Battle for Neutral Europe: British Council Propaganda during the Second World War. London: Bloomsbury.

Delgado, Maria M. and David T. Gies, eds. 2012. A History of Theatre in Spain. Cambridge: Cambridge University Press.

de Toro, Antonio. 2007. La literatura irlandesa en España. La Coruña: Netbiblo.

Fernández, José-Francisco. 2009. "Beckett a Long Time Coming: The Critical Response to Samuel Beckett in Spain and Portugal." In The International Reception of Samuel Beckett, edited by Mark Nixon and Matthew Feldman, 272-290. London: Continuum.

Fiuza, Alexandre Filipe. 2009. "Censura y represión a los músicos españoles y portugueses en las décadas de 1960 y 1970." In Crisis, dictaduras, democracia. I congreso internacional de Historia de Nuestro Tiempo, edited by Carlos Navajas and Diego Iturriaga, 237-247. Logroño: Universidad de La Rioja.

García Ruíz, Víctor. 2007. "El baile de Edgar Neville: un tiempo dormido." In Universo Neville, edited by J. A. Ríos Carratalá, 87-115. Málaga: Instituto Municipal del Libro.

Huerta Calvo, Javier, ed. 2003. Historia del teatro español. Madrid: Gredos.

Hurtley, Jacqueline. 2006. "Lands of Desire: Yeats in Catalonia, Galicia and the Basque Country, 1920-1936." In The Reception of W. B. Yeats in Europe, edited by Klaus Peter Jochum, 76-94. London: Continuum.

Isabel-Estrada, M. Antonia. 2001. "George Bernard Shaw y John Osborne: recepción y recreación de su teatro en España durante el franquismo." PhD diss., Universidad Complutense.

London, John. 1997. Reception and Renewal in Modern Spanish Theatre: 1939-1963. London: Modern Humanities Research Association.

Mahanta Kébé, Serigne. 1994. "Crítica teatral de posguerra en el periódico madrileño Arriba." $\mathrm{PhD}$ diss., Universidad Complutense.

Marques dos Santos, Ana. 2012. "Teatro de Oscar Wilde no palco da Emissora Nacional - os textos." In Depois do Labirinto. Teatro e Traduçao, edited by Manuela Carvalho and Daniela Dipasquale, 273-292. Lisboa: Nova Vega.

Mateo, Marta. 2010. "The Reception of Wilde's Works in Spain Through Theatre Performances at the Turn of the Twentieth Century and Twenty-first Centuries." In The Reception of Oscar Wilde in Europe, edited by Stefano Evangelista, 156-172. London: Continuum.

Merino Álvarez, Raquel, ed. 2007. Traducción y censura en España (1939-1985). Estudios sobre corpus TRACE: cine, narrativa, teatro. Bilbao: Universidad del País Vasco. 
- 2009. "Building TRACE (Translations Censored) Theatre Corpus: Some Methodological Questions on Text Selection." In Translation and Cultural Identity: Selected Essays on Translation and Cross-Cultural Communication, edited by Micaela Muñoz-Calvo and Carmen Buesa-Gómez, 129-153. Newcastle: Cambridge Scholars Publishing.

_ 2012. "A Historical Approach to Spanish Theatre Translations from Censorship Archives." In Iberian Studies on Translation and Interpreting, edited by Isabel García-Izquierdo and Esther Monzó, 123-140. Oxford: Peter Lang.

Merino Álvarez, Raquel and Inés Uribe-Echeverría. 1996. "Spanish Translations of Joyce's Exiles." In The Knowledges of the Translator: From Literary Interpretation to Machine Classification, edited by Malcolm Coulthard and Patricia Anne Odber de Baubeta, 291-298. Lewiston, NY: Edwin Mellen.

Moran, James. 2013. The Theatre of Sean O'Casey. London: Bloomsbury.

Morash, Chris. 2004. A History of Irish Theatre 1601-2000. Cambridge: Cambridge University Press.

Muñoz-Cáliz, Berta. 2006. El teatro crítico español durante el Franquismo visto por sus censores. Madrid: Fundación Universitaria Española.

Pena Rodríguez, Alberto. 2013. "Los grandes héroes ibéricos. Salazar, Franco y la Guerra Civil española: prensa y propaganda." Journal of Spanish Cultural Studies 14 (1): 36-51.

—. 2014. "Mensaje del verdadero Portugal. Los intelectuales portugueses, la II República española y el fascismo ibérico: prensa y propaganda." Arbor 190 (766).

Pérez López de Heredia, María. 2005. "Inventario de las traducciones censuradas de teatro norteamericano en la España de Franco (1939-1963)." In Transvases culturales: literatura, cine y traducción 4, edited by Raquel Merino Álvarez, José Miguel Santamaría and Eterio Pajares, 97-112. Vitoria: Universidad del País Vasco.

Puebla, Lola. 2012. Colección Teatro de Editorial Escelicer. Madrid: Centro Documentación Teatral.

Quirós Alpera, Gabriel. 2010. "Historia de la dirección escénica en España: José Luis Alonso." PhD diss., Universidad Complutense.

Ramos Pinto, Sara. 2010. "Traduçao do vazio: a variaçao linguísica nas traducçoes portuguesas de Pygmalion de Bernard Shaw, e My Fair Lady de Alan Jay Lerner." PhD diss., Universidade de Lisboa.

—. 2012. "Quando o palco e a página se encontram na traduçao." In Depois do Labirinto. Teatro e Traduçao, edited by Manuela Carvalho and Daniela Dipasquale, 213-249. Lisboa: Nova Vega.

Rodríguez Gago, Antonia. 2006. "Beckett después de Beckett." Nexus 2 (11): 72-77.

Rodríguez Villar, Alejandra Juno. 2005. "La cultura teatral en Galicia. El caso de DITEA, 1960-1986." PhD diss., Universidad de Santiago de Compostela.

Seruya, Teresa. 2009. "Introdução a uma bibliografia crítica da tradução de literatura em Portugal durante o Estado Novo." In Traduzir em Portugal durante o Estado Novo, edited by Teresa Seruya, Maria Lin Moniz, and Alexandra Assis Roca, 69-86. Lisboa: Universidade Católica Editora.

Sova, Dawn S. 2004. Banned Plays. Censorship Histories of 125 Stage Dramas. New York: Facts on File.

Spirk, Jaroslav. 2014. Censorship, Indirect Translations and Non-translation: The (Fateful) Adventures of Czech Literature in 20th-Century Portugal. Newcastle: Cambridge Scholars Publishing.

Szmigiero, Katarzyna. 2006. "Fabulism and Irish Censorship." Estudios Irlandeses 1: 112-118.

TETRA Database. "Teatro e Tradução.” Accessed April 30, 2014. http://tetra.letras.ulisboa.pt/base/.

TRACE Database. "Translation and Censorship." Accessed April 30, 2014. http://www.ehu.es/trace/cata logos_eng.php.

Uribe-Echevarría, Inés and Raquel Merino-Álvarez. 1994. "Tradición y traducción: Exiliados de J. Joyce." In Transvases culturales: literatura, cine, traducción 1, edited by Federico Eguíluz et al., 433-444. Vitoria: Universidad del País Vasco. 


\section{APPENDIX}

Table 34.1 Number of entries for plays by Irish authors.

\begin{tabular}{lcccc}
\hline & CETbase & TETRAbase & AGA teat & TRACEti \\
\hline Behan & 0 & 0 & 4 & 1 \\
Beckett & $112\left[1959^{1}\right]$ & 47 & 33 & 22 \\
Joyce & $5\left[1982^{1}\right]$ & 2 & 2 & 3 \\
O'Casey & $10\left[1976^{1}\right]$ & 2 & 12 & 4 \\
Shaw & $7\left[1945^{1}\right]$ & 25 & 24 & 14 \\
Synge & $11\left[1956^{1}\right]$ & 7 & 8 & 1 \\
Wilde & $44\left[1909^{1}\right]$ & 41 & 28 & 18 \\
Yeats & $3\left[1964^{1}\right]$ & 2 & 1 & 1 \\
\hline
\end{tabular}

